\title{
Surveillance and silence:
}

\section{New considerations in assessing difficult social work placements}

\section{Jason Schaub ${ }^{1}$ and Roger Dalrymple ${ }^{2}$}

\begin{abstract}
Studies to date have highlighted a number of key factors in the assessment of difficult social work placements including the need for adequate professional formation; communication; the changing social work education framework; and the influence of the wider social work context. Factors less widely examined are the perceptions of some practice educators that the assessment of placement students operates in a wider context of surveillance and scrutiny by a range of stakeholders. We argue that such perceptions of surveillance can cause a discursive anxiety for practice educators and can inhibit key developmental conversations between assessor and student. Drawing on interviews with ten practice educators, we examine the tendency of practice educators reflecting on a failed placement to rehearse or even enact those key developmental conversations post hoc, broaching previously unstated or tacit aspects of the placement experience. We argue for the need to create a safe discursive space for these conversations to take place in situ during the challenging placement and suggest that a diminution in perceptions of surveillance and enhanced outcomes for students and practice educators will result.
\end{abstract}

Keywords: surveillance; anxiety; practice educators; failing students; discursive spaces; Foucault

1. Senior Lecturer in Social Work, Buckinghamshire New University

2. Principal Lecturer in Education, Oxford Brookes University

Address for correspondence: Jason Schaub, School of Social Sciences, Primary Care and Education, Buckinghamshire New University, Queen Alexandra Road, High Wycombe HP11 2JZ.jason.schaub@bucks.ac.uk

Date of first (online) publication: 24th May 2013

79 J. of Practice Teaching \& Learning 11(3), pp.79-97. DOI: 10.1921/2302110306. () wE-b 
Jason Schaub and Roger Dalrymple

\section{A decade of 'failing to fail'}

The last ten years has seen the emergence of a growing scholarly literature on the issues and challenges involved in difficult social work placements. With Duffy's (2004) foundational work on 'failing to fail' in nursing establishing the starting point, a number of studies have taken up the question of what precisely goes awry in unsuccessful social work placements and what are the problematizing factors in practice assessors adjudging social work students to have failed a placement. Widely-cited studies have highlighted the challenges for practice assessors (across professions) in finding it difficult to fail students (Ilott and Murphy 1997, 1999; Shapton, 2006), and in balancing their role as facilitators of learning with the need to act as professional 'gatekeepers' (Younes, 1998; Crisp and Green Lister, 2002; LaFrance et al., 2004; Holmström and Taylor, 2007). Studies have explored a number of facets of the practice educator's ${ }^{1}$ and placement student's experience including how to support the development of confidence in practice educators (Waterhouse et al., 2011); the importance of relationships between practice educators and students on placement (Lefevre, 2005); and deploying narrative and storytelling in developing struggling social work students (Gibson, 2012). Some commentators have suggested that the social work profession struggles to clearly delineate suitability for practice and to formulate clear criteria (LaFrance et al., 2004; see also Ryan et al., 1997) and have queried the relationship between social work values and the 'failing' of students by asking, 'can we justify excluding people who may be unready rather than unsuitable?' (LaFrance et a.1, 2004:326; see also Waterhouse et al., 2012).

Though the literature base is growing, it is far from complete. Recent writers have lamented the paucity of sustained pedagogic models for facilitating practice education in social work, commenting that there has been 'little research into what works to produce an effective practice learning experience' (Gibson, 2012; see also Carpenter, 2005; Gambrill 2002). Others have found the discussion of the challenges raised by struggling students to be dominated by the students' own views and consider that the experience of the practice educator has been missing or under-represented in the research (Burgess and Phillips, 2000; Gibson, 2012).

The need to fill these perceived gaps has been given fresh impetus by the 2009 observation to the Children and Families Select Committee that social work programmes are 'difficult to fail' (Newman, 2009) and still more recently by the Social Work Reform Board's identification of practice

80 J. of Practice Teaching \& Learning 11(3), pp.59-78. DOI: 10.1921/2202110305. (C) wEb 
Surveillance and silence: Considerations in assessing difficult social work placements

education as an area requiring remodeling (2010a) and the subsequent formation of the new Practice Educator Framework (Social Work Reform Board, 2010b), which began transitional arrangements in October 2012.

Accordingly, this article presents for consideration a further case-study of the challenges and dilemmas involved in the management, supervision and assessment of a difficult placement, going on to offer theoretical elaboration of that data in a manner designed to fill some of the apparent lacunae in the discussion to date. Drawing upon the dominant themes emerging from ten semi-structured interviews conducted with practice educators, we identify notions of surveillance and silence as confounding factors in the difficult placement experience, illuminating the issue with recourse to two theoretical perspectives. First, we contextualise notions of surveillance and scrutiny (dominant themes in the data) in terms of the Foucauldian notion of panopticism, deploying the concept as a way into identifying some of the barriers to successful practice education. We posit that where such perceptions of surveillance obtain, they serve to inhibit key developmental conversations between practice educator and student and increase the anxiety involved for both parties. Second, we mobilise concepts from discourse analysis and literary theory to explore how components of the practice educator interviews effectively serve as rehearsal, enactment or vocalization of precisely those key developmental conversations that were neglected or inhibited in practice. The article concludes with some practical suggestions of pedagogic strategies and interventions that may mitigate against surveillance and silence in the experience of social work practice education.

\section{Gathering the views of practice educators}

A sample of ten practice educators within Southern England, working with a total of seven universities, were interviewed between January and June 2011 as part of a social work research project funded by the Social Policy Higher Education Academy Subject Centre (SWAP), the aim of which was to research practice educators' experiences and views of 'challenging' or 'failing' students on social work placements (Schaub and Dalrymple, 2011). The semi-structured interviews were recorded, transcribed, and analysed following the structure for thematic analysis espoused by Ryan and Bernard (2003).

81 J. of Practice Teaching \& Learning 11(3), pp.79-97. DOI: 10.1921/2302110306. () wËb 
Jason Schaub and Roger Dalrymple

Many of the emergent themes from the resulting cohort data aligned with those identified in other recent case-studies of the kind, salient considerations being communication; the development of student acuity and insight; the challenge of fostering appropriate social work competences and values in challenging students; and the anxiety and isolation experienced by practice educators themselves ${ }^{2}$. Findings concordant with the extant literature may be summarized as follows:

\section{Communication}

In line with other recent studies, the cohort data shows that, in reflecting on a failed or difficult placement, practice educators consider poor communication to have played a central role in the situation. One participant outlined an instance of poor communication, in this case between placement student and service user, thus:

She just started talking to them without any communication about what she was going to do first and actually got this person very distressed - and then she didn't acknowledge this at all. (Participant 5)

Another respondent was emphatic that germane to the role of practice educator is the process of:

teaching people different ways of communicating. If they can learn to communicate in our environment [of a challenging placement] then they can communicate anywhere.

(Participant 6)

The centrality of communication skills in effective social work practice has been cited in almost every social work text, but most recently Richards et al (2005:418) suggest that '[i]t is clear that students need to be taught a range of communication skills' (see also Trevithick, 2005; Luckock et al., 2007). As we elaborate in the latter part of this article, an associated challenge in terms of communication arising from the data was the perception of practice educators that key developmental conversations between themselves and their students had been inhibited, neglected or omitted from the placement experience - something we seek to account for below.

82 J. of Practice Teaching \& Learning 11(3), pp.59-78. DOI: 10.1921/2202110305. @ wEb 
Surveillance and silence: Considerations in assessing difficult social work placements

\section{Student orientation towards practice}

Another prevalent concern amongst the interviewed cohort was student orientation towards practice and engagement with their work. Representative of this theme is the suggestion by one participant that a difficult student was:

[S]omeone that has poor attendance, or is always late - timekeeping issues. Not engaging with me as an assessor. Not being prepared for the sessions we have together. (Participant 9)

while another discerned lack of appropriate engagement with the team and service users as key to failure:

I think I mean, we always ask them to sit in with the group, to observe others working with people, to work in the same sort of way. If, after the first few days, or after a week they're sitting in the back of the room, preferring to observe, that can be a problem. You can learn things by observing, but it's not the same thing as getting involved. (Participant 6)

Such views are again in line with recent findings. Most recently, Gibson (2012) has explored a range of potential reasons for this non- (or dis-) engagement towards practice; and considers student low 'self-efficacy' as a potential source for this difficulty, suggesting more strategic and focussed inputs might be required to ameliorate poor placement performance.

\section{Developing student acuity and insight}

Where the interviews broached the more intangible qualities and attributes of a social worker, students' insight and acuity was a recurrent area of concern raised by interviewees. One participant viewed these qualities as intrinsic to an individual and not amenable to being fostered or instilled by even the most positive of learning environments:

[S]omeone has to have the capacity to develop insight ... you either have it or you don't. I don't think you can teach insight. (Participant 3)

83 J. of Practice Teaching \& Learning 11(3), pp.79-97. DOI: 10.1921/2302110306. () w\&bb 
Jason Schaub and Roger Dalrymple

Equally representative is the view of another practice educator that a failed placement they had overseen was largely due to the students' limited capacity for reflection and insight:

[T] here was no recognition that there [were] any issues... [the student] was therefore not able to understand that what they did wasn't okay. (Participant 4)

while yet another suggested that the student 'had no awareness that this was a problem. Completely unaware' (Participant 1).

Such findings fall into line with earlier studies exploring practice educator concerns over students' capacity and willingness for self-awareness (LaFrance et al., 2004) and open onto consideration of a broader challenge in difficult social work placements - the acquisition of an appropriate base of professional knowledge and values.

\section{Acquisition of social work competences and values}

The data set included plentiful commentary from practice educators on the centrality of considerations of professional identity and values in reaching judgments of failure in placements. Another concern for practice educators was the nascent professional identity of these challenging students. One participant explained how in supporting students to acquire professional attributes and develop their professional identities, she encouraged them to give primacy in their placement to their persona as professional rather than as learner:

You are a social worker first, then a student second. (Participant 2)

The same practice educator went on to state that "professionalism is about being respectful to everybody. Respectful to the clients, respect for other professionals.' This high expectation of professionalism is also found within LaFrance et al.'s study that suggests that practice educators in their study 'attributed considerable importance to the capacity of students for professional interaction' (2004, p.335).

The associated question of students' acquisition of social work values was a further concern for several participants, with one stating '[o]ften you don't have the clear evidence to say that [the challenge] is not something that is

84 J. of Practice Teaching \& Learning 11(3), pp.59-78. DOI: 10.1921/2202110305. (C) wEb 
Surveillance and silence: Considerations in assessing difficult social work placements

within the social work values' (Participant 7). Such findings concur with the suggestion of LaFrance et al. (2004) that practice educators consider a congruence with social work values to be a sine qua non of effective practice, prompting immediate concern over social work students who appeared to engage instrumentally with the profession as another 'job' rather than as a vocation.

In line with the observation of Eraut (1994) and followers that the core of professional knowledge and identity most often resides in those habitual and unconscious behaviours in which professionals engage daily, some of the comments of practice educators interviewed in our simply expressed dissonance with a difficult student's way of being - with how they came across:

There was no passion, no 'fire in her belly'. She wasn't ... keen about social work.

(Participant 5)

In taking up related questions of the acquisition of social work competencies, Vitali (2011) has recently drawn attention to the inadequate correlation of student's self-rating of their performance on placements (the process of 'ipsative' assessment) with the assessments of practice educators and university tutors - an observation that we again find concordant with our view that key developmental conversations (which would surely include the alignment of precisely these kind of views, assumptions and assessments) have a propensity to be inhibited, neglected or even omitted in the context of challenging placements.

\section{Practice educator isolation and anxiety}

Finally, the experiences of the sample population also bore out the observation of Burgess et al. (1998) that the experience of working with a 'difficult' or failing student puts pressure on practice educators (Burgess et al., 1998), and 'may cause them difficulties' (Waterhouse et al., 2011, p.107; see also Beverley \& Worsley, 2007). Basnett and Sheffield (2010,: 2120) suggest that stress is a consistent factor in the practice educator/student relationship when there is a potential of failure, and that they expressed anxiety when their recommendation was overturned by the University; Waterhouse et a.l (2011) found practice educators felt unprepared for

85 J. of Practice Teaching \& Learning 11(3), pp.79-97. DOI: 10.1921/2302110306. (๑) wEb 
Jason Schaub and Roger Dalrymple

Summary mapping of 2011 case-study data against themes identified in the core literature:

\begin{tabular}{|c|c|c|}
\hline Theme & Literature & $\begin{array}{l}\text { Indicative quotations } \\
\text { from the } 2011 \text { cohort data }\end{array}$ \\
\hline Communication & $\begin{array}{l}\text { Richards et al, 2005; } \\
\text { Trevithick, 2005; } \\
\text { Luckock et al, } 2007\end{array}$ & $\begin{array}{l}\text { 'Communication is key to this } \\
\text { field.' (Participant 10) }\end{array}$ \\
\hline $\begin{array}{l}\text { Student orientation } \\
\text { towards practice }\end{array}$ & $\begin{array}{l}\text { Lafrance, 2004; Gibson, } \\
2012\end{array}$ & $\begin{array}{l}\text { 'Not being prepared for the } \\
\text { sessions we have together. You } \\
\text { know, I expect them to come } \\
\text { to the supervisions with an } \\
\text { agenda.' (Participant 9) }\end{array}$ \\
\hline $\begin{array}{l}\text { Developing student } \\
\text { acuity and insight }\end{array}$ & $\begin{array}{l}\text { Lafrance et al, 2004; } \\
\text { Gibson, } 2012\end{array}$ & $\begin{array}{l}\text { 'This constant denial that there } \\
\text { was any problem. ... She lacked } \\
\text { insight.' (Participant 7) }\end{array}$ \\
\hline $\begin{array}{l}\text { Acquisition of social } \\
\text { work competences } \\
\text { and values }\end{array}$ & $\begin{array}{l}\text { Lafrance, 2004; Vitali, } \\
\text { 2011; Gibson, } 2012\end{array}$ & $\begin{array}{l}\text { 'She would try to be non- } \\
\text { judgmental. But then she would } \\
\text { make throw-away comments... } \\
\text { like she was actually biased in } \\
\text { some areas.' (Participant 10) }\end{array}$ \\
\hline $\begin{array}{l}\text { Practice educator } \\
\text { isolation and } \\
\text { anxiety }\end{array}$ & $\begin{array}{l}\text { Burgess et al, 1998; Sharp } \\
\text { \& Danbury, 1999; Duffy } \\
\text { 2004; Shapton, 2006; } \\
\text { Beverley \& Worsley, 2007; } \\
\text { Basnett \& Sheffield, 2010; } \\
\text { Waterhouse et al, 2011 }\end{array}$ & $\begin{array}{l}\text { '... a lonely job' (Participant 2) } \\
\text { 'As a practice teacher, well did } \\
\text { they fail because of something } \\
\text { that I did? (Participant 9) }\end{array}$ \\
\hline
\end{tabular}

marking academic work and failing students. Practice educators found this shift from competence to uncertainty disconcerting. Other research in this field has found that practice educators found the bureaucracy within Higher Education Institutes bewildering, because their exposure to rules and procedures were minimal in comparison with tutors (Shapton, 2006).

Many of the participants in this study suggested that the experience of assessing a challenging student was lonely. Shapton (2006) suggests that the experience of failing a student can leave a practice educator feeling isolated (see also Basnett \& Sheffield, 2010; Duffy 2004). In other research, practice

86 J. of Practice Teaching \& Learning 11(3), pp.59-78. DOI: 10.1921/2202110305. (C) wEb 
Surveillance and silence: Considerations in assessing difficult social work placements

educators also reported anxieties ranging from personalised concerns (such as a former student taking post nearby; or raising concerns/complaints about the practice educator's practice), as well as needing to support the team through the process (Sharp \& Danbury, 1999). Sharp \& Danbury (1999) suggest that placements can often be 'messy and emotionally fraught' (147), with the concomitant threat of appeal or legal action. They suggest that when working with challenging students, practice educators can sometimes feel pressure to consistently typify best practice, with the resulting pressure being difficult to manage.

Indeed, the impact of a difficult student upon the practice educators themselves was one of the strongest themes to emerge from the data. Some participants noted that having a difficult or failing student raised concerns within them regarding their own practice. One participant stated: 'I felt very like we'd failed in some way' (Participant 3). Another suggested that 'I think when you start off with students... it makes you challenge, am I, was it something that I did or didn't do' (Participant 9). She went on to review a student's failure in these terms: 'What was it that we weren't doing that didn't enable her to learn, and questioning our practice, and our methods.' This concern is reflected in a number of other studies, including a recent study by Basnett \& Sheffield (2010), which found stress identified by practice educators in these challenging situations, as well as 'deep sadness' at having to recommend a failing grade (see also Burgess et al., 1998).

In addition to adducing this qualitative data to affirm the findings of recent research in the field, we now seek to elaborate the findings in more theoretical terms with the aim of providing an enabling framework for further contextualisation and inter-relation of practice educators' experiences of challenging placements. First, we apply a theoretical frame of reference to the recurrent observation of the practice educators that they feel, variously, scrutinised, judged, under observation or themselves under assessment. We relate this to the Foucauldian notion of 'pancopticism' and argue that it represents a potentially constraining factor in the pedagogic relationship between practice educator and struggling placement student. Second, we argue that this perception of surveillance inhibits the key developmental conversations that would serve to ameliorate a difficult or failing placement, and call for the identification and creation of an increasing range of 'safe spaces' in which such conversations could indeed take place - to the benefit of both student and educator.

87 J. of Practice Teaching \& Learning 11(3), pp.79-97. DOI: 10.1921/2302110306. () w\&bb 
Jason Schaub and Roger Dalrymple

\section{Perceptions of surveillance: the notion of panopticism}

In its literal form, 'the Panopticon' was a late eighteenth-century conceptual design for prison construction. Conceived by philosopher and social theorist Jeremy Bentham in 1791 though never fully realised in construction, the Panopticon's design sought to afford prison guards maximum supervision of inmates, thus instilling in them an all-pervasive sense of observation and scrutiny. The design placed the guard house at the centre of the structure with the prisoner cells arranged at its periphery. Such a model would leave inmates constantly observable but crucially unable to determine if and when they are being observed, since the arrangement of the structure occluded their sightlines. Struck by the resonance of the Panopticon as metaphor for a wider social phenomenon, social historian Michel Foucault notes how this model for penal institutions served to 'increase both the docility and the utility of all the elements of the system' (Foucault, in Rabinow, 1984: 207) by virtue of its organisation as 'an instrument of perpetual assessment' (1977: 294). He considers how such a sense of all-pervading observation, or surveillance, serves to create anxiety in the 'observed', since the scrutiny is perpetual, allowing no opportunity to retreat 'offstage'. Exploring Panopticon as metaphor, Foucault suggests that there exists the potential for surveillancecreated docility everywhere, what he terms 'the panopticisms of everyday' (1977: 223) which impact or inhibit the engagement of the observed with their environment, on account of a sense of omnipresent oversight.

We suggest that this notion of wider scrutiny and surveillance supplies a helpful context in accounting for the high degrees of anxiety reported by some practice educators. The practice educators in this study suggested a sense of anxiety not only because of perceptions of student scrutiny, but of observation from a number of angles (depicted in figure 1). This sense of surveillance, 'that someone's going to think my practice is bad', was omnipresent for the practice educators, and particularly when the placement was challenging, or potentially at risk of failure.

These concerns for scrutiny actually originated from several orientations: service users; team/peer/organisational; managerial; university; tutor; and from the student - in Foucauldian terms: 'intersecting gazes' (1977). He suggests that this is where social and hegemonic norms are enforced by the subject's heightened awareness of being under surveillance. The concept is a productive one for the situation here described, since it would appear that the practice educators, in their role as auditors and assessors of a student's practice, felt uncertain, observed and under threat (in an inverse Panopticon ${ }^{3}$

88 J. of Practice Teaching \& Learning 11(3), pp.59-78. DOI: 10.1921/2202110305. (C) wEb 
Surveillance and silence: Considerations in assessing difficult social work placements

since the scrutiny takes place from a number of vantage points to a central focus), making the situation fraught with tension. One participant felt there was scrutiny from the university, for 'when you have a failing student, it almost seems that you have to have even more evidence of them failing...' (Participant 8). Another felt scrutiny from the social work profession; 'I think that's a really poor image for the profession' (Participant 4). She went on to note scrutiny from peers and colleagues; 'and other professionals, it all comes out later' (Participant 4). Other participants found it difficult to manage the impact upon their team, or colleagues. One stated that 'it was quite traumatic particularly for my colleague, because the student actually made an allegation directly about her work practice, which she found very upsetting' (Participant 7). Another participant noted that, 'it seemed like her purpose for coming was to find fault with somebody' (Participant 4).

Interestingly in this circumstance, it is the practice educator who is purported to have the power (identified by one participant that suggested that they were 'the one doing the assessing' [Participant 9]), yet they feel 'observed'. It helps to articulate the complex power arrangements that exist within social work practice, and the fragility contained in these practitioners' sense of their place within the profession. This sense of consistent surveillance creates for these practice educators some anxiety and fear, with one participant suggesting that they were frightened of a student: 'she's dangerous, she's going to come in here [to a placement] and wreck somebody's career. Somebody could work their way up for years, and she could come in and say something and that could be their career' (Participant 7). Another suggested that 'We can't fail students, because that will look bad on me' (Participant 8). Foucault (1977) suggests that 'the acquisition of skills is inextricably linked with the establishment of power relations', while Parker (2010: 995) suggests that '[p]ower issues permeate the experience of disrupted placements.' Parker (ibid.) also notes, however, that this power is relational, and can be negative, positive, or informational, depending on the students use.

It is striking that in many of the accounts comprised in the current data set, the role of practice educator is viewed somewhat in isolation. The majority of respondents reflected the sense that whilst the universities were highly supportive, being a practice educator was 'a lonely job', in the words of one of the participants (Participant 2). One potential source for this isolation may arise from the becoming the focus of a number of gazes, with a feeling of 'nowhere to turn'. Foucault suggested that for it to be effective, the Panopticon required 'a faceless gaze that transformed the whole social body into a field of perception' (1977, p.214).

89 J. of Practice Teaching \& Learning 11(3), pp.79-97. DOI: 10.1921/2302110306. () w\&b 
Jason Schaub and Roger Dalrymple

Figure 1: The practice educator experience of scrutiny

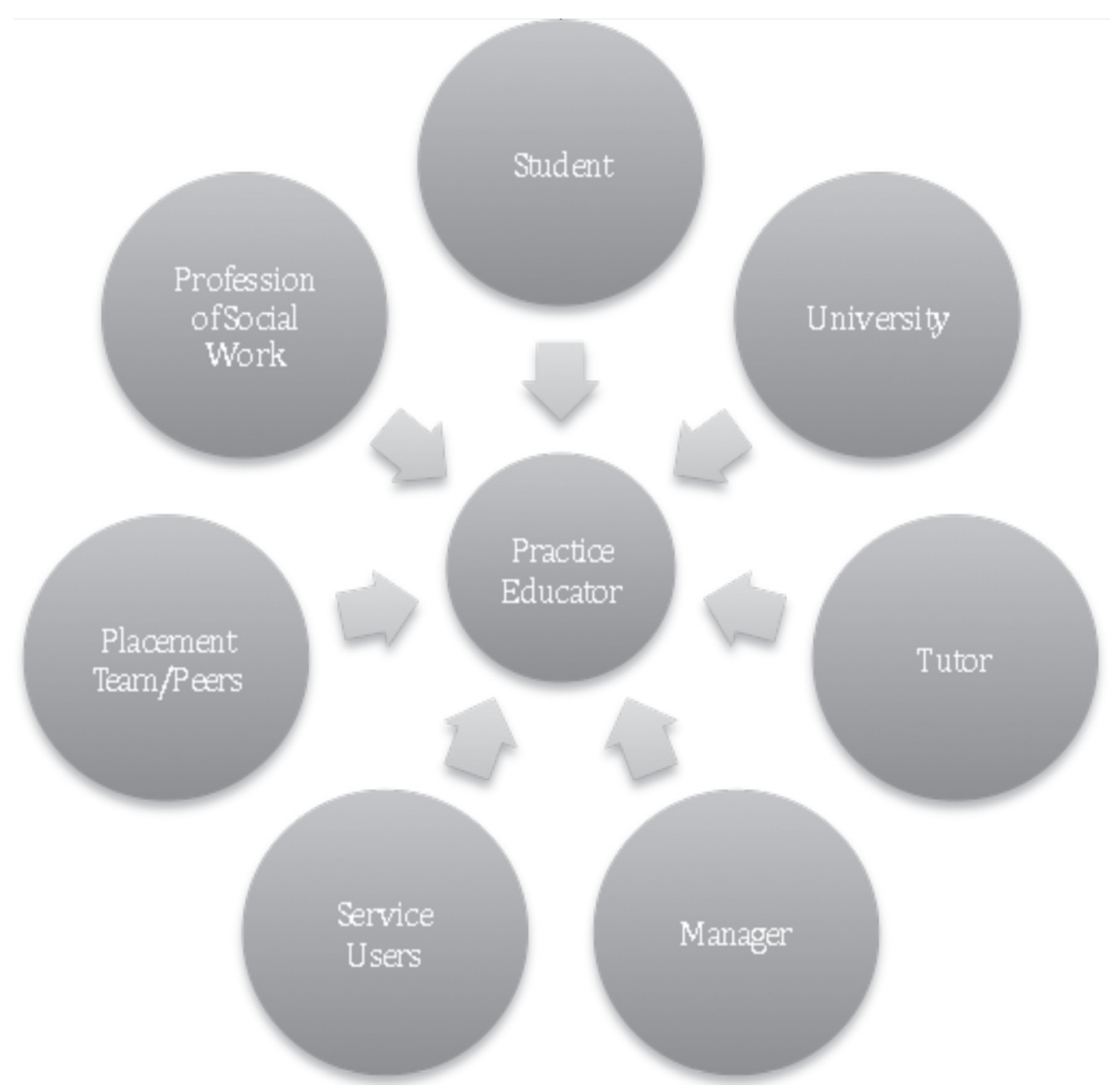

While the literal Panopticon situated the point of invigilation at the centre, an inverted model gives an equal impression of how the practice educator might experience a sense of omnipresent surveillance.

\section{Breaking the silence: Enacting key conversations}

We have suggested that these perceptions of surveillance by some practice educators in the sample are representative of a wider phenomenon in social work practice education, and that such a situation will inhibit communication and, in particular, key developmental conversations between students and educators. It is striking, then, to note that in eight of the ten practice educators interviews conducted for the study, there was an evident tendency to enact or rehearse some of these conversations - and

90 J. of Practice Teaching \& Learning 11(3), pp.59-78. DOI: 10.1921/2202110305. (C) wEb 
Surveillance and silence: Considerations in assessing difficult social work placements

in direct rather than reported speech, as if the challenging student were physically present:

But equally in hindsight I think I should have said, 'You're not well, go away for two weeks. (Participant 1)

I have to know that when I send you out to a family, I have to know I can trust you, and if I can't trust you, you won't be able to become a social worker. (Participant 2)

I think some of my colleagues have found themselves in difficulty because they thought, 'Oh well, the student will get better'. (Participant 3)

Never did [the student] think after that, 'Perhaps she does know what she's talking about, perhaps I'll listen to her a bit more'. (Participant 7)

Everybody seemed to say, 'This is fine' but nobody came up with a solution to try to address it. (Participant 10)

The preoccupation across the sample with what might have been said but which in fact remained unstated is striking. 'I should have said'; 'everybody seemed to say'.

Moreover, many of these rehearsed or enacted conversations were presented in the interviews without any attributions (for example, 'I said', 'she said') but were instead incorporated seamlessly into the free flow of the discussion:

And I hear myself saying that quite a lot with third-year students and you think, well, 'We're half way through and if you were a second-year student I wouldn't be worried at all'. (Participant 1)

Sometimes [the role practice educator involves] being the baddie. 'You've not sent me your log, so I'm not going to be able to look at it'. (Participant 2)

[The student] became sort of aggressive - you know, that sort of silent aggression? Intimidation like, you know, 'What are you doing failing me?' (Participant 2).

Some of [the team] couldn't believe it, probably had an effect on them. 'Oh no, we can't do that again'. (Participant 5)

91 J. of Practice Teaching \& Learning 11(3), pp.79-97. DOI: 10.1921/2302110306. () w\&b 
Jason Schaub and Roger Dalrymple

And they felt, 'Well, why did I fail in the first place, and what's the point in doing it again?' He did do very well, considering. (Participant 6).

Because [the student' was thinking about it and realised that 'I'm out of my depth and I don't know what I'm doing. How am I going to get out of doing this work.' I mean, $[R]$ and I would actually have thought a lot more of her if she'd come to us and said, 'Look, I'm feeling completely out of my depth here' and we would have been very supportive of that. (Participant 7).

The effect is not unlike that achieved in prose narrative where the voice of a narrator merges into the voice of a character within the narrative: a phenomenon known in literary theory and discourse analysis as 'free indirect speech' (Cuddon, 1999). The concept is useful for conveying how seamless in these interviews is the participants' transition from recollecting and reporting an experience to rehearsing it or enacting it as the pressure of the suppressed conversation makes itself felt in the very process of recollection. How different might the experience of a challenging placement have been if these key developmental conversations had indeed taken place in situ with the student, rather than post hoc in the company of a researcher?

\section{Recourse to safer spaces}

If these perceptions of surveillance, scrutiny and fear of failure do indeed serve to inhibit open and reciprocal channels of communication between students on placement and their practice educators, the logical course is to call for practice educators and their students to have greater recourse to safe discursive spaces in which to hold developmental (and potentially difficult) conversations. Ruch has written influentially on the subject of emotional containment in social work practice, and recommends the use of 'safe spaces' in which to 'address the anxieties and uncertainties they face in their practice' (Ruch, 2007: 664). Whilst her original concept was designed for use in child protection practice, it would appear directly applicable to this contiguous setting. These safe spaces are created when 'practitioners felt 'held' by clearly defined organizational and professional frameworks' (ibid.: 670).

In a similar vein, Shapton (2006) adopts an influential concept from Etienne Wenger to call for the wider development of "communities of

92 J. of Practice Teaching \& Learning 11(3), pp.59-78. DOI: 10.1921/2202110305. (C) wEb 
Surveillance and silence: Considerations in assessing difficult social work placements

practice' to support practitioners in all phases of social work practice while Gibson (2012) recommends using a narrative approach to increase 'self-efficacy' in struggling students. This latter approach is particularly resonant given the proclivity in our data sample to enact, vocalize or render in dramatic form some of the key interchanges, episodes or conversations that did (or crucially did not) take place during the unfolding of a difficult placement experience.

With the current revision of the practice educator programme an opportunity exists to embed such discursive space spaces into initial and ongoing training. The model of action learning, for example, has served as a highly effective pedagogy in the broad field of professional education for a number of years (Marsick, 1999) and is well attested as a cogent forum not simply for resolving workplace dilemmas and challenges but also providing precisely the kind of inter-personal support framework perceived as lacking by practice educators. Even in the current context of constrained resources for professional development, small scale action learning programmes could helpfully be adopted as a continuing professional development mechanism for practice educators seeking to address the challenges of difficult placements.

Additionally, our own participants recommended the extension of peersupport opportunities; and the inclusion of management training in practice education modules as valuable strategies to pursue - a number of them explicitly likening managing struggling students to performance-managing members of staff experiencing difficulty.

All such strategies would open opportunities for dialogue between practice educators and struggling students and would at least mitigate the inhibiting effect of perceptions of surveillance and scrutiny for the key parties in the practice education experience. It is our contention that it is by breaking the silence that the perceptions of surveillance diminish and that opportunities are afforded for frank, open (and often difficult) conversations which otherwise might only be rehearsed in hindsight by an isolated practice educator in dialogue only with themselves.

93 J. of Practice Teaching \& Learning 11(3), pp.79-97. DOI: 10.1921/2302110306. (๑) wEb 
Jason Schaub and Roger Dalrymple

\section{Notes}

1 This article uses the term practice educator for anyone who works with students on placement - both those that assess, and those that support, or oversee - sometimes called 'verifiers' or 'on-site supervisors'.

2 This article does not have the scope to discuss all the themes found in the research project. These were: communication; professionalism; values; insight; impact; and engagement and orientation towards practice. The full report can be found at: http://www.swapbox.ac.uk/1151/

3 This concept of the 'inverse Panopticon' has been used previously primarily in surveillance literature, when researching practice in drug treatment courts (Moore, 2011), when 'the many watch one'; in relation to using personal recording devices to observe those in authority (see Mann, 1998; Mann et al, 2003); and also in political commentary about the use of Facebook and Wikileaks to monitor the state (Kim, 2011).

\section{References}

Alperin, D. (1996) Empirical research on student assessment in field education: What have we learned, The Clinical Supervisor, 14, 1, 149-161

Basnett, F. and Sheffield, D. (2010) The Impact of Social Work Student Failures upon Practice Educators. British Journal of Social Work, 40, 7, 2119-2136

Beverley, A. and Worsley, A. (2008) Learning and Teaching in Social Work Practice. Basingstoke: Palgrave Macmillan

Burgess, R., Campbell, V., Phillips, R. and Skinner, K. (1998) Managing Unsuccessful or Uncompleted Placements. Journal of Practice Teaching, 7, 4-12

Crisp, B. R. and Green Lister, P. (2002) Assessment Methods in Social Work Education: A Review of the Literature. Social Work Education, 21, 2, 260-269

Cuddon, J. A. (1999) Penguin Dictionary of Literary Terms and Literary Theory. London: Penguin

Dingwall, R., Eekelaar, J. and Murray, T. (1983) The Protection of Children: State Intervention and Family Life, Oxford, Blackwell

Duffy, K. (2004) Failing Students. London: Nursing and Midwifery Council

Eraut, M. (1994) Developing Professional Knowledge and Competence, Abingdon: Routledge

Foucault, M (1977) Discipline and Punish: The birth of the prison. New York: Random House

94 J. of Practice Teaching \& Learning 11(3), pp.59-78. DOI: 10.1921/2202110305. @ wEb 
Surveillance and silence: Considerations in assessing difficult social work placements

Furness, S. and Gilligan, P. (2004) Fit for Purpose: Issues from practice placements, practice teaching and the assessment of students' practice. Social Work Education, 23, 4, 465-479

Gambrill, E. (2002) Evaluating The Outcomes Of Social Work Practice: A pilot program. Journal of Social Work Education, 38, 3, 355-62

Gibson, M. (2012) Narrative Practice and Social Work Education: Using a narrative approach in social work practice education to develop struggling social work students. Practice, 1-13

GSCC (2007) Social Work Education in England: Delivering Quality, Recognising Success: The 2007 Social Work Education Quality Assurance Report. London: GSCC

GSCC (2010) Raising Standards: Social work conduct in England 2003-08. London: GSCC

Holmström, C. and Taylor, I. (2008) Mapping the Terrain of Selection for Social Work: A critical analysis of policy, theory and research. Social Work Education, $27,5,519-535$

Ilott, I. and Murphy, R. (1997) Feelings and Failing in Professional Training: the assessor's dilemma. Assessment and Evaluation in Higher Education, 22, 307-316

Ilott, I. and Murphy, R. (1999) Success and Failure in Professional Education: Assessing the Evidence, London: Whurr

Kim, J. (2011) Arrival of the Inverse Panopticon Society: From Wikileaks to the Facebook revolution, Tokyo: Discover 21

LaFrance, J., Gray, E. and Herbert, M. (2004) Gate-keeping for professional social work practice. Social Work Education, 23, 3, 325-340

Lefevre, M. (2005) Facilitating Practice Learning and Assessment: The influence of relationship. Social Work Education, 24, 5, 565-583

Luckock, B., Lefevre, M. and Tanner, K. (2007) Teaching and learning communication with children and young people: developing the qualifying social work curriculum in a changing policy context. Child and Family Social Work, 12, 2, 192-201

Mann, S. (1998) 'Reflectionism' and 'diffusionism': New tactics for deconstructing the video surveillance superhighway. Leonardo, 31, 2, 93-102

Mann, S., Nolan, J., and Wellman, B. (2003) Sousveillance: inventing and using wearable computing devices for data collection in surveillance environments, Surveillance and Society, 1, 3, 331-355

Moore, D. (2011) The Benevolent Watch: Therapeutic surveillance in drug treatment court Theoretical Criminology, 1, 3, 255-268

Marsick, V. J. (1999) The Many Faces of Action Learning, Management Learning, 30, 2, 159-176

Newman, M. (2009) Social work degrees difficult to fail, MPs told. Times Higher

95 J. of Practice Teaching \& Learning 11(3), pp.79-97. DOI: 10.1921/2302110306. (๑) wEb 
Jason Schaub and Roger Dalrymple

Education Supplement. Available from: <http://www.timeshighereducation. co.uk/story.asp?storyCode $=407667$ andsectioncode $=26>$ [Accessed 25 June 2011]

Parker, J. (2010) When things go wrong! Placement disruption and termination: Power and student perspectives. British Journal of Social Work, 40 (3, 983-999

Proctor, A. K. (1993) Tutors Professional Knowledge of Supervision and the Implications for Supervision Practice. in J. Calderhead and P. Gates (Eds.) Conceptualizing Reflection in Teacher Development. London: Falmer

Rabinow, P. (1984) The Foucault Reader. New York: Pantheon Books

Rai, G.S. (2004) International fieldwork experience: A survey of US schools, International Social Work, 47, 2, 213-226

Raymond, G. T. (2000) Gatekeeping in field education. in P. Gibbs and E.H. Blakely (Eds.) Gatekeeping in BSW Programs. New York: Colombia University Press

Redfern, S., Norman, I., Calman, L., Watson, R. and Murrells, T. (2002) Assessing competence to practise in nursing: A review of the literature. Research Papers in Education, 17, 1, 51-77

Richards, S., Ruch, G. and Trevithick, P. (2005) Communication Skills Training for Practice: The ethical dilemma for social work education. Social Work Education, $24,4,409-422$

Royse, P. (2000) The Ethics of Gatekeeping. in P. Gibbs and E.H. Blakely (Eds.) Gatekeeping in BSW Programs. New York: Colombia University Press

Ruch, G. (2007) Reflective practice in contemporary child-care social Work: The role of containment. British Journal of Social Work, 37, 4, 659-680

Ryan, G.W. and Bernard, H.R. (2003) Techniques to Identify Themes. Field Methods, 15, 85-109

Ryan, M., Habibis, D. and Craft, C. (1997) Guarding the Gates of the Profession: Findings of a survey of gatekeeping mechanisms in Australian Bachelor of Social Work programs. Australian Social Work, 50, 3, 5-12

Shapton, M. (2006) Failing to Fail: Is the assessment process failing the caring profession? Journal of Practice Teaching and Learning, 7, 2, 39-54

Sharp, M. and Danbury, H. (1999) The Management of Failing DipSW Students: Activities and exercises to prepare practice teachers for work with failing students. Aldershot: Ashgate

Schaub, J. and Dalrymple, R. (2011) 'She didn't seem like a social worker': Practice educators' experiences and perceptions of assessing failing social work students on placement. http://www.swapbox.ac.uk/1151/

Social Work Reform Board (2010a) Building a Safe and Confident Future: One year on Progress report from the Social Work Reform Board. London: Department for Education

96 J. of Practice Teaching \& Learning 11(3), pp.59-78. DOI: 10.1921/2202110305. (C) wEb 
Surveillance and silence: Considerations in assessing difficult social work placements

Social Work Reform Board (2010b) Practice Educator Professional Standards for Social Work. London: Department for Education

Trevithick, P. (2005) Social Work Skills: A practice handbook. (2nd ed.) Maidenhead: Open University Press

Vitali, S. (2011) The acquisition of social work competencies. Social Work Education, 30. 2, 236-246

Waterhouse, T., McLagan, S. and Murr, A. (2011) From practitioner to practice educator: What supports and what hinders the development of confidence in teaching and assessing student social workers? Practice, 23, 95-110.

Younes, M.N. (1998) The gatekeeping dilemma in undergraduate programs: Collision of ideal and reality. International Social Work, 41, 145-153.

97 J. of Practice Teaching \& Learning 11(3), pp.79-97. DOI: 10.1921/2302110306. ๑ wE-b 